\title{
ガスタービン燃焼器の燃焼性能に及ほすシラン添加効果*
}

\author{
塚 本 達 郎*1, 長谷川進*1 \\ 佐 藤 順 一*2, 新 岡 蔐*1

\section{Effect of Silane Addition on Combustion Performance of Gas Turbine Combustor}

\author{
Tatsuro TSUKAMOTO, Susumu HASEGAWA, \\ Jun'ichi SATO and Takashi NIIOKA
}

\begin{abstract}
Lean blow-off limit and ignitable limit were studied experimentally to understand the effect of silane addition on the combustion performance of the gas turbine combustor. The fuel employed was methane. Silane concentration was varied up to $5 \%$. The results show that silane addition to methane extends both the lean blow-off limit and ignitable limit considerably, and that this effect is more remarkable in the region of higher air velocity. It is concluded that silane addition makes the flame stable and promotes combustion reaction in the wide range of fuel-air ratio. However, silicon dioxide produced by silane burning adheres to the inner side of the combustor and accumulates around the fuel injection holes.
\end{abstract}

Key Words: Combustion, Gas Turbine Combustor, Blow-off Limit, Ignition, Silane

\section{1. 緒}

モノシラン $\left(\mathrm{SiH}_{4}\right.$ : 以下単にシランと呼ぶ)は非常 に反応性が高く, 空気と混合するだけで自発着火して 燃焼するので非常に危険であるが，その高反応性をう まく利用できれば有用である，スペースプレーン用ス クラムジェットエンジンの燃焼室では, 空気流速が非 常に大きいために火炎の安定化および着火が困難であ る。そこで，燃焼室内に反応性の高いシランを噴射し たり，燃料にシランを添加することによって，火炎を 安定化したり着火を促進したりすることが考えられて いる(1).また，シランは半導体製造過程で用いられて おり，微量ではあるが半導体工場での廃ガスにシラン が含まれる，危険を回避するため，水置換により水素 などへ転換することも行われているが，水素も安全で あるとはいえない，そこで, 燃料希薄である廃ガスに 他の燃料を混入して積極的にシランを燃焼させて, 安 全な物質に変えてから排出することが考えられる。

ここでは，燃料への少量のシラン添加が燃焼および

* 原稿受付 平成 2 年 7 月 18 日.

*1 证員，東北大学流体科学研究所（９９80 仙台市青葉区片平 2 $1-1)$.

*2 正員. 无川島播磨重工業(株)技術研究所（１355 東京都江東 区豊洲 3-1-15).
着火現象に及ぼす効果を調べるために，高負荷の小形 ガスタービン燃焼器を用いて，燃料のメタンにシラン を混入した場合の火炎吹飛び限界および着火限界の測 定を行った。これは，シラン添加による二つの限界の 拡大効果を枋らったものである。また, シランを添加 して燃焼させる場合の安全性ならびに問題点を検討し た.

\section{2. 実験装置およひ方法}

実験に用いた小形ガスタービン燃焼器を図 1 に示 す. 燃焼器は, ライナ径約 $70 \mathrm{~mm}$, ライナ長さ約 200 $\mathrm{mm}$, ケーシング内径 $100 \mathrm{~mm}$ の偏流缶形である。燃 焼用空気はケーシングの側面から導入される。燃焼用 空気が側面から導入され, それが燃焼器ライナの空気 孔に直接当たるとライナ内の流速分布に偏りが生じや すい。そこで, ライナの周囲にバッフルすなわちアウ タライナを取付けた。導入された空気はアウタライナ の外側を流れ，燃焼器頭部へ導かれる。一次燃焼域へ の空気は, 燃焼器頭部のスワーラおよび側面の空気孔

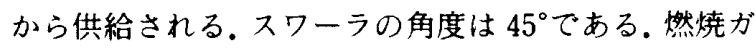
スは直径 $2 \mathrm{~mm}$ で 6 孔の多孔噴射弁を用いてライナ

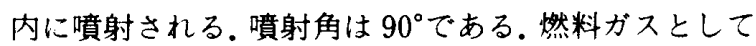
はメタンを用いた。着火にはエネルギー $16 \mathrm{~J} ， 6$ スパ 
ーク/s の容量形スバークプラグを用いた.

図 2 に実験装置全体の概略を示す。送風機からの空 気は，整流筒を通して側部より常温常圧で燃焼器に流 入する.このとき空気流量は整流筒出口に置いたピト 一管によって測定した。メタンは流量をオリフィス流 量計で測定した後に燃焼器へ供給される、シランは, 4 倍の窒素で希釈されたもの(シラン $20 \%+$ 窒素 $80 \%$ )を用いたが，この程度希釈されていても空気中 に放出されるだけで，自発着火してだいたいの炎と白 煙 $\left(\mathrm{SiO}_{2}\right)$ を出して燃焼する。したがって，シランの配 管に空気が存在すると，管内で燃焼して危険であるの で, シランの配管系は真空ポンプで引いた後に窒素で パージできるようになっている。シランは,オリフィ ス流量計によって流量を計測された後に燃焼器入口直 前でメタンと混合される。

吹飛び限界の測定は以下のように行った。メタンの 流量を所定の值に調整して, 空気流量を安定限界内に して着火し，空気流量を徐々に増加して，火炎が吹き 飛ぶ空気流量を求めるのが通常である。しかし，シラ ンを混入した場合には、 シランの流量が微量であるた めに, 空気流量を変化させると燃焼器内の圧力の微少 変化によってシランの流量も変化してしまい, 測定誤 差が大きくなる。このため, 空気流量を一定にし、メ夕 ンあるいはシランの流量を隇少させるという方法で吹 飛び限界を求めた。なお，燃料過洤限界は，実用上必要

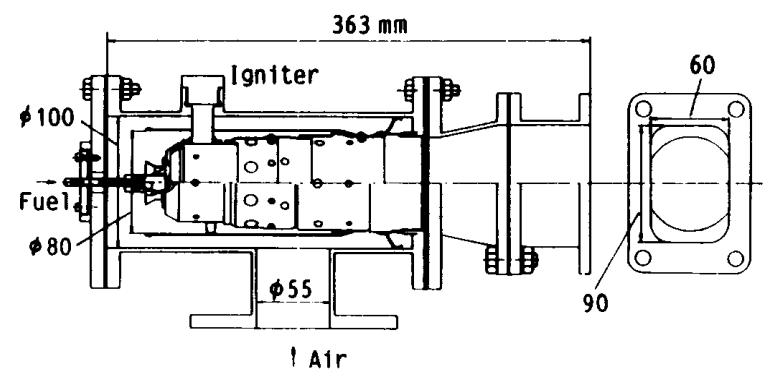

図1実験に用いたガスタービン燃焼器

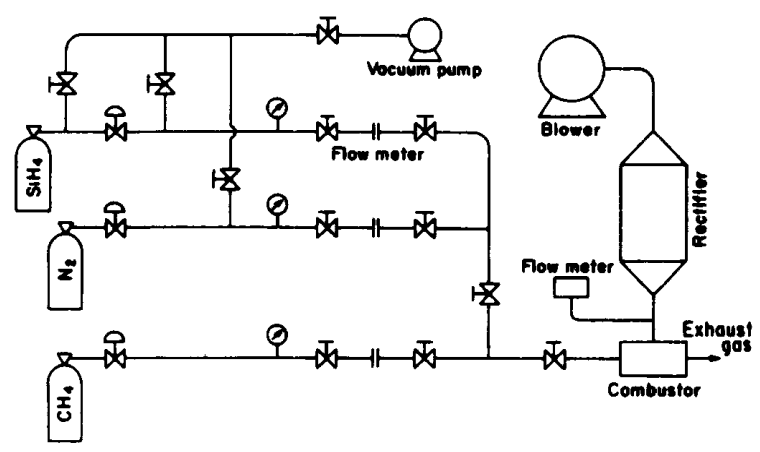

図 2 供給系の概略図
なくまた実験上危険を伴うため,ここでは希薄限界の み測定した。

着火限界の測定は, 空気, メタンおよびシランの流 量を所定の値に調整した後に, 火花放電させて行っ た.エネルギー $16 \mathrm{~J}$ の火花を 6 回/ $\mathrm{s}$ 放電させた。測定 においては，最初の火花放電開始後 $5 \mathrm{~s}$ 以内に着火し, 放電を停止しても引き続き燃焼が持続する場合を着火 するとした。したがって, $5 \mathrm{~s}$ 放電しても着火しないか, 着火しても放電を停止すると燃焼が持続しない場合に は着火限界外とした。着火限界も吹飛び限界同様, 希 薄限界のみ測定した。

また, 燃焼器出口断面における温度分布を線径 0.3 $\mathrm{mm}$ のクロメルーアルメル熱電対を用いて測定した。 なお，使用した送風機の性能上，測定は吹飛び，着火 限界とも空気流量 800〜 $5000 \mathrm{~L} / \mathrm{min}$ の範囲で行った。

\section{3. 実験結果および考宗}

3.1 火资吹飛ひ限界図 3 に火炎吹飛び限界の 実験結果を示す， 2 章で述べたように，空気流量を一 定にし，吹飛び時のメタンとシランの流量をプロット したものである.ある空気流量に対して, 実線の右上 側のシラン流量とメタン流量の組合せでは火炎は安定 し，左下側では吹き飛ぶ。したがって，シランを添加す ることによって, 同じ空気流量でも少ないメタン流量 まで吹き飛ばないことがわかる，図 3 の実験結果から 内插によってシランの添加量をパラメータにして, 実 験結果を整理しなおしたものが図 4 である。縦軸がメ タン流量, 横軸が空気流量である.シランを添加して いない場合には，前述のとおり空気流量を增大させて 吹飛び限界を調べられるので, 実験点も示されてい る.図 4 中，たとえば $1 \% \mathrm{SiH}_{4}+4 \% \mathrm{~N}_{2}$ added の曲線

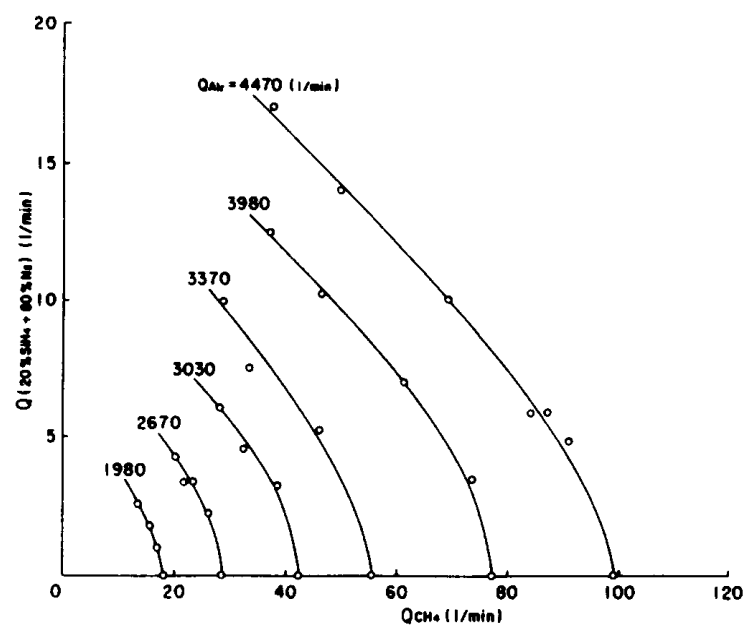

図 3 シラン添加時の吹飛び限界 
は、縦軸に示されたメタンの流量に $1 \%$ のシランと 4\%の窒素が含まれている場合の結果である. 図 4 か ら, シランの添加によって同時にその 4 倍の窒素が加 えられているにもかかわらず，吹飛び限界がかなり拡 大していることがわかる．図 5 は, 図 4 の縦軸を燃空 比に横軸を代表空気流速に変換したものである。ただ し，燃空比を求めるときの燃料流量にはシランと窒素 が含まれており，また代表空気流速は空気流量をライ ナの断面積で除した值である.

燃焼器内での火炎の吹飛び現象は，液体燃料の蒸発 特性時間, 空気力学的特性時間(燃料と空気の混合時 間および燃焼器内の滞留時間)，化学反応の特性時間 などの特性時間によって整理できる(2). 気体然料を用 いた場合には，このうち空気力学的特性時間 $\tau_{a}$ と化 学反応の特性時間 $\tau_{c}$ の競合によって吹飛び現象が支 配されると考えられる ${ }^{(3)}$. すなわち，相対的に $\tau_{a}$ が大 きけれが火炎は安定し，祦が小さければ吹き飛ぶ。こ こで用いた燃焼器では燃料噴出速度が十分に大きく， 然料と空気の混合は良好であると思われるので，燃料 と空気の混合時間は無視して, $\tau_{a}$ として燃焼器内の滞

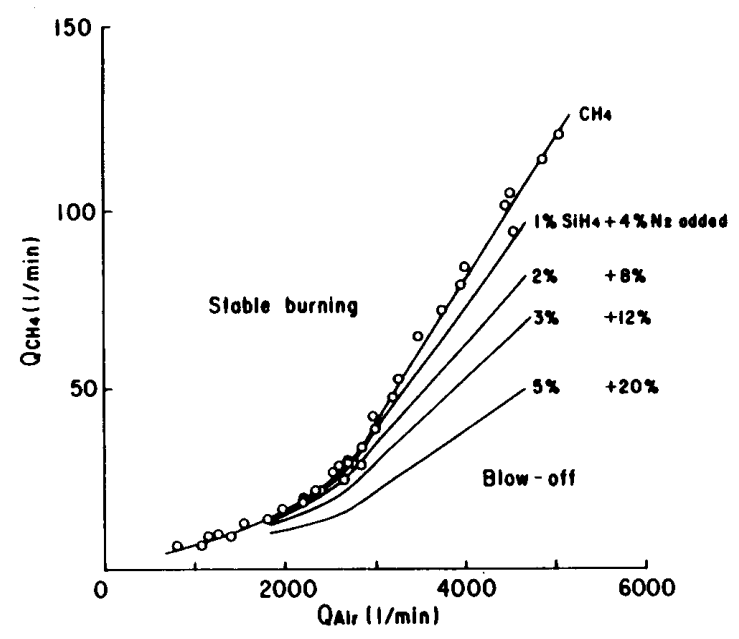

図 4 吹飛び限界(空気流量に対する燃料流量)

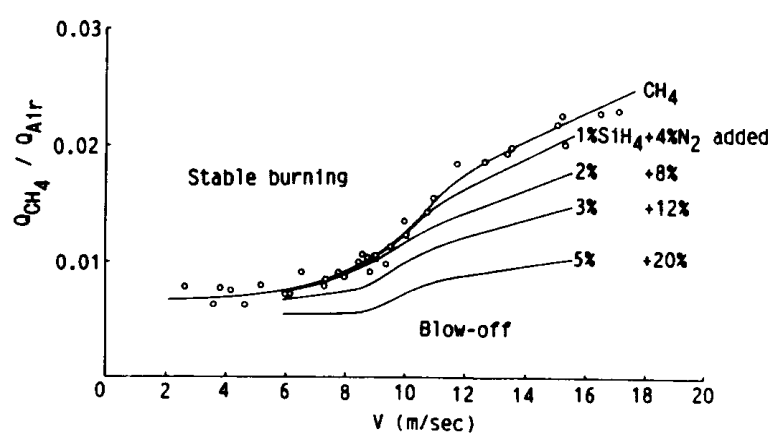

図 5 吹我び限界(代表空気流速に対する燃空比)
留時間をとり， $\tau_{c}$ として密度を総括反応速度で割って 表すと， $\tau_{a}$ および $\tau_{c}$ はそれぞれ次のように表される。 $\tau_{a}=L / V, \tau_{c}=\rho / \dot{\omega}$

ここで，Lは燃焼器長さ，Vは空気流速， $\rho$ は混合気

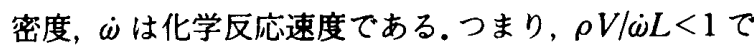
あれば吹飛びは生じない。

燃料に添加物を混入することによる吹飛び限界拡大 の理由としては，単位燃料流量あたり発熱量の增大ま たは化学反応の促進が考えられる．図 5 の吹飛び曲線 において，もし燃料の発熱量が增大したとすると，そ の効果は燃料流量割合の增加すなわち燃空比の増加と 等しいので, 限界が図 5 の下方へ広がって, 同じ空気 流速でもより燃料希薄な領域まで保炎できるようにな ると考えられる．また，化学反応が促進される場合に

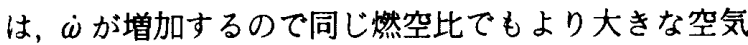
流速まて保炎できるようになり，限界が図 5 の右へ移 動する. 図 5 の綎軸の然料流量は, メタンと添加物の 合計流量を表しており，添加物を加えた場合にはメ夕 ンの流量は隇少していることになる。燃料の真発熱量 はメタンが $803 \mathrm{~kJ} / \mathrm{mol}$, シランが $1426 \mathrm{~kJ} / \mathrm{mol}$ であ るので，たとえばメタンにシラン $5 \%+$ 窒素 $20 \%$ が含 まれる場合には，発熱量は $674 \mathrm{~kJ} / \mathrm{mol}$ となり，メ夕 ンだけの場合よりも減少している。したがって, 図 5 では限界は右のほうへ広がっているとみるべきであ り, シラン添加はその高反応性による総括的な反応速 度の增加の効果があると考えてよい。

図 5 において, $V=10 \mathrm{~m} / \mathrm{s}$ の付近で吹飛び限界が 急に変化する領域があり, シランを添加した場合も同 様の傾向である．この領域は図 4 においては傾きが急 に変化している空気流量 $3000 \mathrm{~L} / \mathrm{min}$ の領域に相当す

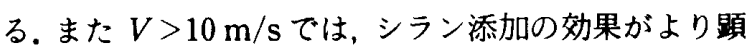
著であることがわかる．燃料噴射口から噴出した燃料 は，その周囲から流入した空気と混合して，噴射口近 くで保炎されて燃焼しているが，空気流速が大きくな ると保炎位置が下流へ移動する。ここでは，V=10 $\mathrm{m} / \mathrm{s}$ においてこの保炎位置の移動が起こり, 安定性は より悪くなって，図 5 のように限界が急激に上方へ移 動したと考えられる。また，安定性の悪い領域である ためシラン添加効果が大きく，空気流速の大きいとこ ろほど下方への限界の広がりの程度は大きくなる。

図 6 に燃焼器出口断面の温度分布の測定結果を示 す. シランの添加によって出口断面における温度は全 体的に上昇し，より均一になっている。これはシラン の反応促進効果のために保炎位置が上流側へ移動し， 燃焼器内で反応，混合とも十分に行われるためである と考えられる。 


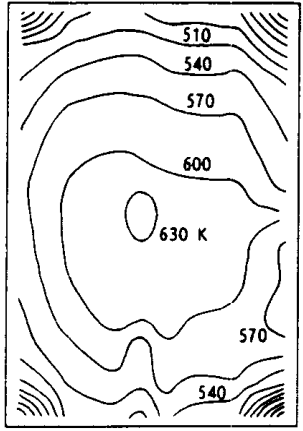

空父流革 $3700 \mathrm{~L} / \mathrm{min}$ くタン流早 $94 \mathrm{~L} / \mathrm{min}$ シラン穿素灌度 $0 / 0 \%$

(a) シランない

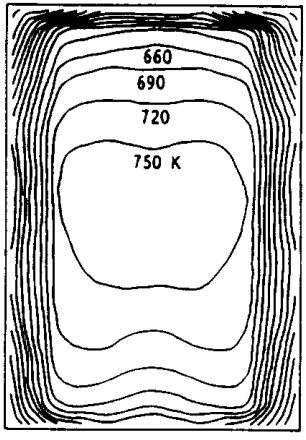

$3700 \mathrm{~L} / \mathrm{min}$ $94 \mathrm{~L} / \mathrm{min}$ $2 / 8 \%$

b ） シラン添加
図 6 燃焼器出口断面の温度分布

3 -2 蒴火限界 図 7 に着火限界の測定結果を示 す、吹飛びのときと同様に，緥軸は燃空比で，横軸は代 表空気流速である。なお、シランを添加しない場合だ け実験点を入れてあるが、シラン添加の場合は，吹飛 び限界のときと同様の内插によって求めた。つまり， 空気流量を一定にし，メタンとシランの流量を変化き せて着火する限界を求めることを，数種類の空気流量 に対して䘕った結果である。シランを添加することに よって，同じ空気流量でも少ないメタン流量まで着火 することがわかる．図７中の破線は、シランを添加し ない場合の吹飛ざ限界を示している，着火限界の空気 流速に対する変化は，吹飛び限界上ほほ同様であり， シランを添加した場合の限界の広がり方も同じような 傾向を示す。着火の場合も吹飛び限界と同様に空気流 速 $10 \mathrm{~m} / \mathrm{s}$ 付近で限界の急激や変化がみられるが，こ の原因としては，この空気流速者境にして保炎位置が 移動していることが考えられる，空気流速が大きいほ ビシラン添加の効果が大きくなるのは，吹飛び限界の 場合と闰様の理由による。

$3 \cdot 3$ シラン添加の凮題点安全性確保のために シラン供給の配管系が複雑になったが, 手順よ゙おり行 えば実験は危険なく行えた。また，シランの添加によ つて異常然焼など生じることもなく，図 5 および図 7 にみられるようにより火炎の安定性が増すことがわ かり，これはシランの燃焼処理の立場からも歓迎すべ きことである。ただ唯一の問題点は、シランの燃焼に 上って生成さ机る二酸化けい素 $\left(\mathrm{SiO}_{2}\right)$ が，燃焼室壁面 および燃料噴射口に付着することである。このため， 長時間燃焼させるとその厚さが増して, 然焼器内部の 流れが変化することが予想される，実際，総燃焼時間

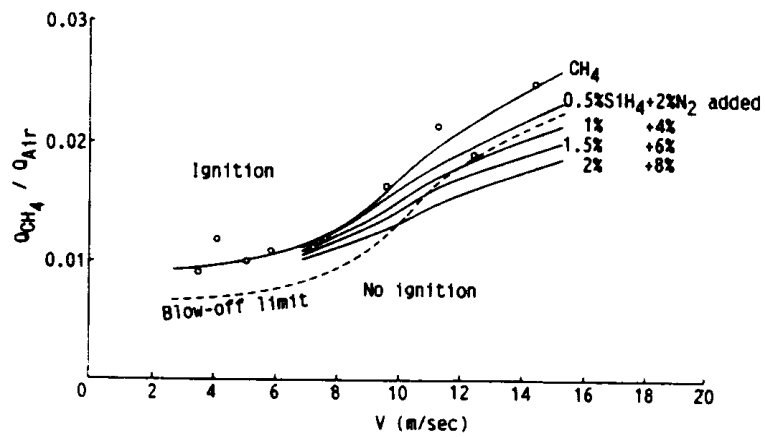

図 7 着火限界の測定結果

約 $1 \mathrm{~h}$ の後に, 燃料噴射口の直径 $2 \mathrm{~mm}$ の穴の周りに は厚さ約 $5 \mathrm{~mm} の \mathrm{SiO}_{2}$ がたい積しており，圧力損失 増大のため燃料の上流圧力を高くする必要があった。 また，ライナの二次空気取入れ用の穴の周囲にも約 1 $\mathrm{mm} の \mathrm{SiO}_{2}$ がたい積した。ここで実験した範囲では， $\mathrm{SiO}_{2}$ のたい積は吹飛び限界および着火限界にはほと んど影響はなかったが，さらに長時間の燃焼では影響 がでることも予想される。したがって，定期的な燃焼 器の清掃が必要となる。 また燃料噴射部, 二次空気取 入れ孔などに $\mathrm{SiO}_{2}$ のたい積しにくい設計が要求され る.

\section{4. 結 铪}

小形ガスタービン燃焼器を用いて燃料のメタンに少 量のシランを加えた場合の希薄側の吹飛び限界および 着火限界の測定を行い, 以下のことがわかった。

（1）シランの添加は吹飛び限界および着火限界の 拡大に大きな効果がある。またその効果は、空気流速 が大きいはど顕著である。

（2）高反応性のため危険であるシランは, 長時間 燃焼させると燃焼器内に $\mathrm{SiO}_{2}$ が析出するという問題 点沙あるものの，燃料に混入することによって安全に 燃焼処理することができる。

本研究の一部注, 鹿島学術振興財団および大日本ス クリーン製造(株)の研究助成によるものであり、ここ に謝意を表する。

\section{文献}

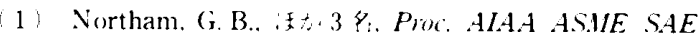

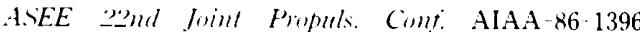
1986 .

2: Plee. S. L. and Mellor, A.M.. Combust. Flame, 35 $(1979) 61 \cdot 80)$

3 Sato.J. and Sato. Y. Pros. ASME J SUEE Thermal Fug. Jinit cont. 4 (198.3), 22i-231 